\title{
Front Matter: Volume 10551
}

, "Front Matter: Volume 10551," Proc. SPIE 10551, Optical Data Science: Trends Shaping the Future of Photonics, 1055101 (8 May 2018); doi: 10.1117/12.2322766

SPIE. Event: SPIE OPTO, 2018, San Francisco, California, United States 


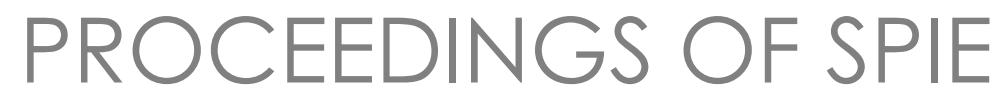

\section{Optical Data Science: Trends Shaping the Future of Photonics}

Bahram Jalali

Editor

30-31 January 2018

San Francisco, California, United States

Sponsored and Published by

SPIE 
The papers in this volume were part of the technical conference cited on the cover and title page. Papers were selected and subject to review by the editors and conference program committee. Some conference presentations may not be available for publication. Additional papers and presentation recordings may be available online in the SPIE Digital Library at SPIEDigitallibrary.org.

The papers reflect the work and thoughts of the authors and are published herein as submitted. The publisher is not responsible for the validity of the information or for any outcomes resulting from reliance thereon.

Please use the following format to cite material from these proceedings:

Author(s), "Title of Paper," in Optical Data Science: Trends Shaping the Future of Photonics, edited by Bahram Jalali, Proceedings of SPIE Vol. 10551 (SPIE, Bellingham, WA, 2018) Seven-digit Article CID Number.

ISSN: 0277-786X

ISSN: 1996-756X (electronic)

ISBN: 9781510615878

ISBN: 9781510615885 (electronic)

Published by

SPIE

P.O. Box 10, Bellingham, Washington 98227-0010 USA

Telephone +1 3606763290 (Pacific Time) · Fax +1 3606471445

SPIE.org

Copyright @ 2018, Society of Photo-Optical Instrumentation Engineers.

Copying of material in this book for internal or personal use, or for the internal or personal use of specific clients, beyond the fair use provisions granted by the U.S. Copyright Law is authorized by SPIE subject to payment of copying fees. The Transactional Reporting Service base fee for this volume is $\$ 18.00$ per article (or portion thereof), which should be paid directly to the Copyright Clearance Center (CCC), 222 Rosewood Drive, Danvers, MA 01923. Payment may also be made electronically through CCC Online at copyright.com. Other copying for republication, resale, advertising or promotion, or any form of systematic or multiple reproduction of any material in this book is prohibited except with permission in writing from the publisher. The CCC fee code is 0277 $786 \mathrm{X} / 18 / \$ 18.00$.

Printed in the United States of America.

Publication of record for individual papers is online in the SPIE Digital Library.

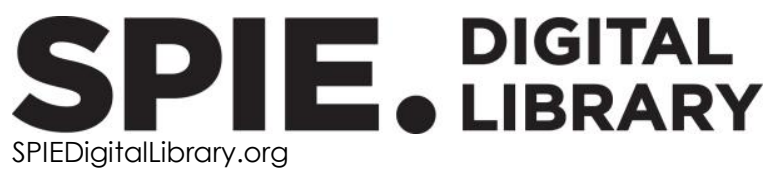

Paper Numbering: Proceedings of SPIE follow an e-First publication model. A unique citation identifier (CID) number is assigned to each article at the time of publication. Utilization of CIDs allows articles to be fully citable as soon as they are published online, and connects the same identifier to all online and print versions of the publication. SPIE uses a seven-digit CID article numbering system structured as follows:

- The first five digits correspond to the SPIE volume number.

- The last two digits indicate publication order within the volume using a Base 36 numbering system employing both numerals and letters. These two-number sets start with $00,01,02,03,04$, 05, 06, 07, 08, 09, OA, OB ... 0Z, followed by 10-1Z, 20-2Z, etc. The CID Number appears on each page of the manuscript. 


\title{
Contents
}

\author{
$\checkmark$ Authors \\ vii Conference Committee
}

\section{DATACENTERS AND MOBILE COMPUTING}

1055102 Spectral efficiency in crosstalk-impaired multi-core fiber links [10551-1]

1055103 Ultra high-definition video: convergence toward 100Gbps and beyond for digital A/V connectivity with fiber optics [10551-2]

1055106 Low-latency optical parallel adder based on a binary decision diagram with wavelength division multiplexing scheme [10551-5]

\section{EMERGING TECHNIQUES}

10551 OK Silicon photonics for neuromorphic information processing [10551-19]

10551 OL Compact and cost-effective multi-channel optical spectrometer for fine FBG sensing in loT technology [10551-20]

10551 OM Application of laser speckle to randomized numerical linear algebra [10551-21]

10551 ON Highly sensitive method of temperature sensing by using heterodyne detection [10551-22] 
Proc. of SPIE Vol. 10551 1055101-4

Downloaded From: https://www.spiedigitallibrary.org/conference-proceedings-of-spie on 26 Apr 2023 Terms of Use: https://www.spiedigitallibrary.org/terms-of-use 


\title{
Authors
}

Numbers in the index correspond to the last two digits of the seven-digit citation identifier (CID) article numbering system used in Proceedings of SPIE. The first five digits reflect the volume number. Base 36 numbering is employed for the last two digits and indicates the order of articles within the volume. Numbers start with 00, 01, 02, 03, 04, 05, 06, 07, 08, 09, OA, OB...0Z, followed by 10-1Z, 20-2Z, etc.

\author{
Agrell, Erik, 02 \\ Awaji, Yoshinari, 02 \\ Bienstman, Peter, OK \\ Choi, Young-Wan, ON \\ Dambre, Joni, OK \\ Freiberger, Matthias, OK \\ Inoue, K., 06 \\ Ishihara, T., 06 \\ Jeon, Su-Jin, ON \\ Johannson, Leif, OM \\ Jung, Mi, ON \\ Katumba, Andrew, OK \\ Kim, Eudum, ON \\ Kim, Ji-Hoon, ON \\ Kim, Sun-Ho, ON \\ Kita, S., 06 \\ Klaus, Werner, 02 \\ Konishi, Tsuyoshi, OL \\ Laporte, Floris, OK \\ Lugnan, Alessio, OK \\ Luís, Ruben S., 02 \\ Nguyen, Nguyen X., 03 \\ Notomi, M., 06 \\ Nozaki, K., 06 \\ Parekh, Devang, 03 \\ Park, Jun-Hee, ON \\ Puttnam, Benjamin J., 02 \\ Rademacher, Georg, 02 \\ Scofield, Adam C., OM \\ Sefler, George A., OM \\ Shaw, Thomas J., OM \\ Shinya, A., 06 \\ Stapleton, Andrew D., OM \\ Valley, George C., OM \\ Wada, Naoya, 02 \\ Yamasaki, Yu, OL
}


Proc. of SPIE Vol. 10551 1055101-6

Downloaded From: https://www.spiedigitallibrary.org/conference-proceedings-of-spie on 26 Apr 2023 Terms of Use: https://www.spiedigitallibrary.org/terms-of-use 


\title{
Conference Committee
}

\author{
Symposium Chairs
}

Connie J. Chang-Hasnain, University of California, Berkeley (United States)

Graham T. Reed, Optoelectronics Research Centre, University of Southampton (United Kingdom)

Symposium Co-Chairs

Jean Emmanuel Broquin, IMEP-LAHC (France)

Shibin Jiang, AdValue Photonics, Inc. (United States)

Program Track Chair

David L. Andrews, University of East Anglia (United Kingdom)

Conference Chair

Bahram Jalali, University of California, Los Angeles (United States)

Conference Co-Chairs

Ken-ichi Kitayama, The Graduate School for the Creation of New Photonics Industries (Japan)

Ata Mahjoubfar, University of California, Los Angeles (United States)

Conference Program Committee

Mehdi Asghari, Mellanox Technologies, Inc. (United States)

Claire Lifan Chen, Lumentum (United States)

Shahab Etemad, Telcordia Technologies, Inc. (United States)

Yeshaiahu Fainman, University of California, San Diego (United States)

Cejo K. Lonappan, University of California, Los Angeles (United States)

Masaya Notomi, NTT Basic Research Laboratories (Japan)

Nasser N. Peyghambarian, College of Optical Sciences, The University of Arizona (United States)

Paul R. Prucnal, Princeton University (United States)

Daniel R. Solli, University of California, Los Angeles (United States) and Universität Göttingen (Germany)

Madhuri Suthar, University of California, Los Angeles (United States)

Naoya Wada, National Institute of Information and Communications Technology (Japan) 


\section{Session Chairs}

1 Datacenters and Mobile Computing

Cejo Konuparamban Lonappan, University of California, Los Angeles (United States)

2 Artificial Intelligence

Madhuri Suthar, University of California, Los Angeles (United States)

3 Deep Learning Microscopy and Learning

Jacky C. K. Chan, University of California, Los Angeles (United States)

4 Emerging Techniques

Ken-ichi Kitayama, The Graduate School for the Creation of New Photonics Industries (Japan) 